\title{
The mercury resistance operon of the IncJ plasmid pMERPH exhibits structural and regulatory divergence from other Gram- negative mer operons
}

Department of Genetics and Microbiology, Donnan Laboratories, University of Liverpool, PO Box 147, Liverpool L69 3BX, UK

\author{
A. M. Osborn, K. D. Bruce, D. A. Ritchie and P. Strike \\ Author for correspondence: A. M. Osborn. Tel: +44 151794 4410. Fax: +44 1517944401. \\ e-mail:metal@liv.ac.uk
}

\begin{abstract}
The bacterial mercury resistance determinant carried on the Ind plasmid PMERPH has been characterized further by DNA sequence analysis. From the sequence of a 4097 bp Bg/ll fragment which confers mercury resistance, it is predicted that the determinant consists of the genes merT, merP, merC and merA. The level of DNA sequence similarity between these genes and those of the mer determinant of Tn21 was between 56.4 and $62.4 \%$. A neighbourjoining phylogenetic tree of merA gene sequences was constructed which suggested that pMERPH bears the most divergent Gram-negative mer determinant characterized to date. Although the determinant from pMERPH has been shown to be inducible, no regulatory genes have been found within the BgIII fragment and it is suggested that a regulatory gene may be located elsewhere on the plasmid. The cloned determinant has been shown to express mercury resistance constitutively. Analysis of the PMERPH mer operator/promoter (O/P) region in vivo has shown constitutive expression from the mer $\mathbf{P}_{\mathrm{TCPA}}$ promoter, which could be partially repressed by the presence of a trans-acting MerR protein from a Tn21-like mer determinant. This incomplete repression of mer $\mathrm{P}_{\mathrm{TCPA}}$ promoter activity may be due to the presence of an extra base between the -35 and -10 sequences of the promoter and/or to variation in the MerR binding sites in the O/P region. Expression from the partially repressed $m e r P_{\text {TCPA }}$ promoter could be restored by the addition of inducing levels of $\mathrm{Hg}^{2+}$ ions. Using the polymerase chain reaction with primers designed to amplify regions in the merp and merA genes, $1.37 \mathrm{~kb}$ PMERPH-like sequences have been amplified from the IncJ plasmid R391, the environmental isolate SE2 and from DNA isolated directly from non-cultivated bacteria in River Mersey sediment. This suggests that pMERPH-like sequences, although rare, are nevertheless persistent in natural environments.
\end{abstract}

Keywords: pMERPH, mer operon, mercury resistance in bacteria

\section{INTRODUCTION}

Bacterial resistance to mercury $\left(\mathrm{Hg}^{\mathbf{R}}\right)$ is widespread in clinical and environmental isolates, in both Gram-negative and Gram-positive bacteria, and has a global dis-

Abbreviations: CAT, chloramphenicol acetyltransferase; O/P, operator/ promoter.

The EMBL accession numbers for the nucleotide sequence of the PMERPH operon and of the pHG106 merA region reported in this paper are Z49146 and $Z 49200$, respectively. tribution (Summers, 1986; Foster, 1987). Resistance, often borne on plasmids and/or transposons, is encoded by the genes of the mer operon, of which the best studied are those borne on the transposons $\operatorname{Tn} 501$ and $\operatorname{Tn} 21$. Resistance to inorganic mercury (narrow spectrum resistance) is mediated by a NADPH-dependent reduction of inorganic $\mathrm{Hg}^{2+}$ ions to the less toxic $\mathrm{Hg}^{0}$ which volatilizes from the cell surface. This reaction is catalysed by mercuric reductase, the product of the $\operatorname{mer} A$ gene. In addition to $\operatorname{mer} A$, the mer operon consists of two or three genes encoding transport proteins $(\operatorname{mer} T, \operatorname{mer} P$ and $\operatorname{mer} C)$ and two regulatory genes (merR and merD). Broad 
Table 1. Plasmids and constructs

\begin{tabular}{|c|c|c|c|}
\hline Plasmid & $\begin{array}{c}\text { Relevant } \\
\text { phenotype* }\end{array}$ & Construct & Source \\
\hline pBluescript $\mathrm{KS}^{+}$ & $A p^{R}$ & - & Stratagene \\
\hline pACYC184 & $\mathrm{Cm}^{\mathrm{R}} \mathrm{Tc}^{\mathrm{R}}$ & - & Chang \& Cohen (1978) \\
\hline pKK232.8 & $A p^{R}$ & - & Brosius (1984) \\
\hline pHG106 & $A p^{R} T^{R} \mathrm{Hg}^{\mathrm{R}}$ & $\begin{array}{l}4.2 \mathrm{~kb} \text { HindIII broad spectrum mer } \\
\text { from pDU1358 into pBR322 }\end{array}$ & Griffin et al. (1987) \\
\hline pMERPH & $\mathrm{Hg}^{\mathrm{R}}$ & - & Peters et al. (1991) \\
\hline R391 & $\mathrm{Km}^{\mathbf{R}} \mathrm{Hg}^{\mathbf{R}}$ & - & Coetzee et al. (1972) \\
\hline pSP100 & $\mathrm{Cm}^{\mathrm{R}} \mathrm{Hg}^{\mathrm{R}}$ & $\begin{array}{l}4 \cdot 1 \mathrm{~kb} B g / \mathrm{II} \text { pMERPH mer into } \\
\text { pLV59 }\end{array}$ & Peters et al. (1991) \\
\hline pSE20R1 & $\mathrm{Ap}^{\mathrm{R}} \mathrm{Hg}^{\mathrm{S}}$ & $\begin{array}{l}0.52 \mathrm{~kb} \text { merR O/P PCR product } \\
\text { from SE20 into } \mathrm{KS}^{+}\end{array}$ & Osborn et al. (1995) \\
\hline pPH101 & $A p^{R} H_{g}{ }^{R}$ & $B g / \mathrm{II} 4.1 \mathrm{~kb}$ from pSP100 into $\mathrm{KS}^{+}$ & \\
\hline pPH102 & & $\begin{array}{l}\text { HincII-A } 0.77 \mathrm{~kb} \text { from pPH101 into } \\
\mathrm{KS}^{+}\end{array}$ & \\
\hline pPH103 & & $\begin{array}{l}\text { HincII-D } 0.63 \mathrm{~kb} \text { from pPH101 } \\
\text { into } \mathrm{KS}^{+}\end{array}$ & \\
\hline pPH104 & & $\begin{array}{l}\text { HincII-B } 0.38 \mathrm{~kb} \text { from } \mathrm{pPH} 101 \text { into } \\
\mathrm{KS}^{+}\end{array}$ & \\
\hline pPH105 & & $\begin{array}{l}\text { HincII-C } 1.0 \mathrm{~kb} \text { from } \mathrm{pPH} 101 \text { into } \\
\mathrm{KS}^{+}\end{array}$ & \\
\hline pPH106 & & $\begin{array}{l}\text { HincII-E } 1.32 \mathrm{~kb} \text { from } \mathrm{pPH} 101 \text { into } \\
\mathrm{KS}^{+}\end{array}$ & \\
\hline pPH107 & & $\begin{array}{l}\text { SstI } / \text { HindIII } 0.27 \mathrm{~kb} \text { from } \mathrm{pPH} 102 \\
\text { into } \mathrm{KS}^{+}\end{array}$ & \\
\hline pPH108 & $\mathrm{Ap}^{\mathrm{R}} \mathrm{Hg}^{\mathrm{S}}$ & $\begin{array}{l}\text { HindIII } / \text { HincII } 0.33 \mathrm{~kb} \text { from } \\
\text { pPH102 into } \mathrm{KS}^{+}\end{array}$ & This study \\
\hline pPH109 & & $\begin{array}{l}\text { HindIII } 0.18 \mathrm{~kb} \text { from } \mathrm{pPH} 102 \text { into } \\
\mathrm{KS}^{+}\end{array}$ & \\
\hline pPH110 & & $\begin{array}{l}\text { KpnI/ClaI } 0.5 \mathrm{~kb} \text { from } \mathrm{pPH} 105 \text { into } \\
\mathrm{KS}^{+}\end{array}$ & \\
\hline pPH111 & & ClaI $0.5 \mathrm{~kb}$ from pPH105 into $\mathrm{KS}^{+}$ & \\
\hline pPH112 & & $\begin{array}{l}\text { Blunted HincII/SstI from pPH102 } \\
\text { into SmaI pKK232.8 }\end{array}$ & \\
\hline pPH113 J & & $\begin{array}{l}\text { As pPH112 but in opposite } \\
\text { orientation }\end{array}$ & \\
\hline pACSE20R & $\mathrm{Tc}^{\mathrm{R}} \mathrm{Cm}^{\mathrm{s}} \mathrm{Hg}^{\mathrm{s}}$ & $\begin{array}{l}\text { PvuII } 1 \mathrm{~kb} \text { from pSE20R } 1 \text { into } \\
\text { pACYC184 }\end{array}$ & \\
\hline
\end{tabular}

* Ap, ampicillin; $\mathrm{Cm}$, chloramphenicol; $\mathrm{Hg}$, mercuric ion ; $\mathrm{Km}$, kanamycin; Tc, tetracycline; $\mathrm{R}$, resistant ; $S$, sensitive.

spectrum resistance to organomercurials in addition to $\mathrm{Hg}^{2+}$ is conferred by the product of the merB gene which cleaves the organo group from the mercuric ion, prior to reduction of $\mathrm{Hg}^{2+}$ by MerA (for a review, see Misra, 1992). Expression of the mer operon is inducible and is controlled by MerR, which binds to the mer operator/ promoter $(\mathrm{O} / \mathrm{P})$. In the absence of $\mathrm{Hg}^{2+}$ ions MerR represses expression. On addition of $\mathrm{Hg}^{2+}$ ions, the MerR-mer $\mathrm{O} / \mathrm{P}$ complex undergoes a conformational change which allows RNA polymerase to transcribe the structural genes (for a review, see Summers, 1992).

In Gram-negative bacteria a distinct subset of closely related mer determinants (represented by $\operatorname{Tn} 501, \operatorname{Tn} 21$, pKLH2 and pMER419) has been identified and is commonly found in bacteria from natural environments and in clinical isolates from around the globe (Osborn $e t$ al., 1995). Peters et al. (1991) identified novel mercury resistance determinants from the conjugative IncJ plasmids pMERPH and R391, which were believed to be integrated into the chromosome. Both determinants confer narrow spectrum mercury resistance and detoxify $\mathrm{HgCl}_{2}$ by reduction and subsequent volatilization. Maxicell polypeptide analysis identifed four polypeptides of which three were of similar size to the MerP, MerC and MerA polypeptides of $\operatorname{Tn} 21$. However, the $\mathrm{pMERPH}$ and 
R391 mer determinants failed to hybridize to the Gramnegative mer determinants of $\operatorname{Tn} 501$ and $\operatorname{Tn} 21$ at a stringency which detected DNA homologies of greater than $70 \%$. In addition, these mer determinants, although inducible, did not trans-complement MerR mutants of Tn21 (Foster \& Ginnity, 1985). Initial studies into the frequency of pMERPH-like sequences in natural environments suggests they are relatively rare when compared with those of the Tn501/Tn21/pKLH2/pMER419 subgroup (Peters et al., 1991).

The aims of the present study were threefold: firstly, to determine the DNA sequence of the mer determinant of PMERPH to allow comparison with the other mer determinants sequenced to date; secondly, to investigate the regulation of the pMERPH mer operon; and finally, to attempt to identify using PCR other pMERPH-like sequences in the natural environment.

\section{METHODS}

Bacterial strains, plasmids and oligonucleotides. Escherichia coli strains used were $\mathrm{AB} 1157\left(\mathrm{Sm}^{\mathrm{R}} \mathrm{F}^{-}\right.$thi-1 thr-1 leu-6 pro $A 2$ argE3 his-4 rpsL31 supE44 galK2 lacY1 ara-14 xyl-5 mtl-1 ts $x$-33) and XL-1-Blue (supE44 bsdR $17 \mathrm{rec} A 1$ end $A 1$ gyr $A 96$ thi-1 rel $A 1$ lac $\left\{\mathrm{F}^{\prime}\left[\right.\right.$ pro $A B^{+}$lac $I^{q}$ lac $Z \Delta M 15 \mathrm{Tn} 10\left(\right.$ tet $\left.\left.\left.^{\mathrm{R}}\right)\right]\right\}$. XL-1-Blue was used as the host strain for all DNA manipulations, except for the construction of PACSE20R. AB1157 was used as the host strain in the promoter probe experiments and as the host for the conjugative plasmids pMERPH and R391. The environmental strain SE2 $\left(\mathrm{Hg}^{\mathrm{R}}\right)$ was isolated from a sediment sample taken from Fiddlers Ferry, River Mersey (Osborn et al., 1993). Plasmids (Table 1) were propagated in E. coli. Oligonucleotides used in this study are listed in Table 2.
Cloning and sequencing. DNA fragments for sequencing were subcloned into pBluescript $\mathrm{KS}^{+}$using standard protocols (Sambrook et al., 1989). Template DNA was prepared by alkaline lysis (Birnboim \& Doly, 1979) and further purified by caesium chloride density gradient centrifugation. PMERPH subclones were sequenced on both strands using Sequenase 2.0 (USB) with the M13-20 and Reverse (RP) primers together with a number of custom-synthesized primers (Table 2). The $\mathrm{pHG} 106$ mer $A$ region was sequenced on both strands using an ABI 373A DNA automated sequencer with the primers $1358 \mathrm{E} 3$ and $1358 \mathrm{E} 5$.

The promoter probe clones pPH112 and pPH113 were constructed by ligation of a $0.7 \mathrm{~kb}$ blunt-ended HincII/SstI fragment from pPH102 bearing the pMERPH mer $\mathrm{O} / \mathrm{P}$ region into the promoter probe vector $\mathrm{pKK} 232.8$ in both orientations. The mer $\mathrm{R}$ and mer $\mathrm{O} / \mathrm{P}$ region of the $\mathrm{Tn} 21$-like $\mathrm{Hg}^{\mathrm{R}}$ determinant from SE20 was subcloned from pSE20R1 (Osborn et al., 1995) into the PvuII site of pACYC184 and insert-bearing clones identified by the insertional inactivation of the chloramphenicol resistance gene.

Sequence and numerical analysis. The pMERPH mer sequence was analysed using the UWGCG suite of sequence analysis programs (Devereux et al., 1984). Evolutionary relationships between mer $A$ gene sequences were constructed using the methods described by Osborn et al. (1995).

Chloramphenicol acetyltransferase (CAT) assays. Crude protein extracts were made by Brij lysis (Forster, 1984) prior to assaying for CAT activity by direct measurement of the production of $\left[{ }^{14} \mathrm{C}\right]$ acetyl chloramphenicol (Shaw, 1975). Briefly, $0.5 \mathrm{ml}$ of an overnight culture was added to $50 \mathrm{ml}$ Luria Broth (LB) and shaken at $37^{\circ} \mathrm{C}$ at 200 r.p.m. for $30 \mathrm{~min} . \mathrm{HgCl}_{2}$ was added to a final concentration of $2 \mu \mathrm{M}$ for induction experiments and then the cultures were grown for a further $30 \mathrm{~min}$. Cells from $10 \mathrm{ml}$ of culture were harvested by centri-

Table 2. Oligonucleotides

\begin{tabular}{|c|c|}
\hline Oligonucleotide & Sequence \\
\hline M13 reverse primer & 5'-AAC AGC TAT GAC CAT G-3' \\
\hline M13 - 20 primer & $5^{\prime}$-GTA AAA CGA CGG CCA GT-3' \\
\hline $102 \mathrm{~A}$ & $5^{\prime}$-CAA TAG CGG CAA TAA CAC-3' \\
\hline $103 \mathrm{~A}$ & 5'-TAC CCG AGC AAG GGA TCT-3' \\
\hline $103 \mathrm{~B}$ & 5'-CTG CTC GGT TCC ATC AT-3' \\
\hline $103 \mathrm{C}$ & $5^{\prime}$-TCC ACG CCA ACC ATT CCT-3' \\
\hline $103 \mathrm{D}$ & 5'-GTT GTG CTG GGT AAC GA-3' \\
\hline $104 \mathrm{~A}$ & $5^{\prime}$-GCC TGA ACG CTT TAG CT-3' \\
\hline $105 \mathrm{~A}$ & 5'-GTT TGG TTG CTT TCA GTG-3' \\
\hline $105 B$ & 5'-TGT TTG CCT GGA TTG CCT-3' \\
\hline $106 \mathrm{~A}$ & 5'-ACC GCC CGT GCA CTT TGA-3' \\
\hline $106 \mathrm{~B}$ & $5^{\prime}$-AAG AGC AAG CCA ACG CA-3' \\
\hline $106 \mathrm{C}$ & $5^{\prime}-\mathrm{CT}^{\prime} \mathrm{T}$ CT'T AGG CT'T AAG CG-3' \\
\hline $106 \mathrm{D}$ & 5'-GTT GTG CTG GGT AAC GA-3' \\
\hline $106 \mathrm{E}$ & 5'-CTC CAC CAT AGT CAG GT-3' \\
\hline $106 \mathrm{~F}$ & 5'-GTG GTG ATG GT'T ATA AG-3' \\
\hline $110 \mathrm{~A}$ & $5^{\prime}-\mathrm{GAC}$ TGC TGT GAC AAC GA-3' \\
\hline $111 \mathrm{~A}$ & 5'-CGT TGA G'TA CCA AGG CA-3' \\
\hline $1358 \mathrm{E} 3$ & 5'-AGC GTG CGA CTG TCG GTT-3' \\
\hline $1358 \mathrm{E} 5$ & 5'-TGC CGA AGG GAT CAA GGT-3' \\
\hline
\end{tabular}


fugation at 10000 r.p.m. for $3 \mathrm{~min}$, and the resultant pellet was resuspended in $0.4 \mathrm{ml} 25 \%$ sucrose $/ 0.01 \mathrm{M}$ Tris, $\mathrm{pH} \mathrm{8.0.}$ EDTA $(30 \mu \mathrm{l}, 0.1 \mathrm{M}, \mathrm{pH} 7 \cdot 8)$ and lysozyme $\left(40 \mu \mathrm{l}, 1 \mathrm{mg} \mathrm{ml}^{-1}\right.$ in $0.01 \mathrm{M}$ Tris, $\mathrm{pH} 8.0$ ) were added, the vessel contents mixed by inversion and left on ice for $2 \mathrm{~min} . \mathrm{MgSO}_{4}$ was added to a final concentration of $50 \mathrm{mM}$ together with $100 \mu \mathrm{l} 5 \%$ Brij-58, the vessel contents mixed by inversion and left on ice for $1 \mathrm{~h}$. Cell debris was pelleted by microcentrifugation at 10000 r.p.m. for $15 \mathrm{~min}$. CAT activity was assayed after incubation of $20 \mu \mathrm{l}$ crude protein extract with $40 \mu \mathrm{l} 0.25 \mathrm{M}$ Tris, $\mathrm{pH} 8.0,20 \mu \mathrm{l} 8 \mathrm{mM}$ chloramphenicol and $20 \mu \mathrm{l}$ acetyl-CoA mixture $(18 \mu \mathrm{l} 0.5 \mathrm{mM}$ acetyl-CoA and $2 \mu \mathrm{l}\left[{ }^{14} \mathrm{C}\right]$ acetyl-CoA $(3.7 \mathrm{kBq})$ at $37^{\circ} \mathrm{C}$ for $1 \mathrm{~h}$. Ethyl acetate $(0.8 \mathrm{ml})$ was added, and the mixture briefly vortexed prior to microcentrifugation at 13000 r.p.m. for $15 \mathrm{~s}$. A portion $(0.7 \mathrm{ml})$ of the upper organic layer was then added to $4 \mathrm{ml}$ Econofluor scintillation fluid (NEN) and assayed for the presence of ${ }^{14} \mathrm{C}$-labelled chloramphenicol 3-acetate in an LKB Rackbeta scintillation counter, compared against reagent blanks. CAT activity was calculated as the mean value from at least three experiments.

PCR amplification and hybridization analysis of mer regions. Template DNA from $\mathrm{Hg}^{\mathbf{R}}$ bacteria was prepared as described previously (Osborn et al., 1993). DNA isolated directly from soil was prepared by the method of Bruce $e t$ al. (1992). PCR products were amplified using Taq DNA polymerase $(2.5 \mathrm{U})$ with the primers $104 \mathrm{~A}$ and $103 \mathrm{~B}$. Reactions were performed for either 30 cycles $\left(94^{\circ} \mathrm{C}\right.$ for $1 \mathrm{~min}, 48^{\circ} \mathrm{C}$ for $1 \mathrm{~min}, 72^{\circ} \mathrm{C}$ for $2 \mathrm{~min}$ ) for crude bacterial extract or 35 cycles for purified soil DNA, followed by 1 cycle of $72^{\circ} \mathrm{C}$ for $10 \mathrm{~min}$. Primer, dNTP (dATP, dCTP, dGTP and dTTP) and $\mathrm{MgCl}_{2}$ concentrations were $30 \mathrm{pmol}, 50 \mu \mathrm{M}$ and $1.5 \mathrm{mM}$, respectively. PCR products were visualized following electrophoresis on $0.7 \%$ agarose TBE gels containing ethidium bromide $\left(1 \mu \mathrm{g} \mathrm{m}^{-1}\right)$. Following Southern transfer, hybridization with the $4 \cdot 1 \mathrm{~kb} B g / \mathrm{II}$ mer fragment from pSP100 was performed as described previously (Osborn et al., 1993) at a stringency to detect DNA homologies greater than $70 \%$. Membranes were exposed to Fuji RX film for $20-60 \mathrm{~min}$ at $-70^{\circ} \mathrm{C}$.

\section{RESULTS}

\section{Sequence and evolutionary analysis of the structural mer genes of pMERPH}

Analysis of the DNA sequence of the $4097 \mathrm{bp} \mathrm{Bg} / \mathrm{II}$ fragment from pMERPH identified four putative mer genes $(\operatorname{mer} T, \operatorname{mer} P, \operatorname{mer} C$ and $\operatorname{mer} A$ ) on the basis of homology to published mer sequences (Fig. 1). The predicted proteins encoded by these genes were of similar size to those of the Tn21 mer determinant. However the predicted protein sequences differed significantly from those of Tn21, for example $57.8 \%$ identity and $71.5 \%$ similarity for MerA, and $49.1 \%$ identity and $67.5 \%$ similarity for MerT. Analysis of the predicted sequence of the MerA protein of pMERPH identified an additional eight cysteine residues when compared against those of Tn21 and Tn501 (Fig. 1), whilst the other eight cysteine residues were conserved with those of $\mathrm{Tn} 21$. No such increase was found in the number of cysteine residues in the predicted sequences of MerT, MerP or MerC of pMERPH. Furthermore the positions of the cysteine residues in these proteins was conserved between $\operatorname{Tn} 21$ and pMERPH. The MerA protein of pMERPH was most closely related to that from the Thiobacillus ferrooxidans
$\mathrm{Hg}^{\mathbf{R}}$ determinant (Inoue et al., 1989) (59.1\% identity, $74 \cdot 6 \%$ similarity), whilst the MerA proteins of the Grampositive $\mathrm{Hg}^{\mathbf{R}}$ determinants were the most distantly related to that of pMERPH, for example pI258 showed $41.6 \%$ identity and $62.9 \%$ similarity (Laddaga et al., 1987). A neighbour-joining (Saitou \& Nei, 1987) phylogenetic tree of $\operatorname{mer} A$ gene sequences was constructed (Fig. 2). The previously incomplete sequence of the $\operatorname{mer} A$ gene of pDU1358 (Griffin et al., 1987; Nucifora et al., 1989) was completed by sequencing a $300 \mathrm{bp}$ region, to enable the pDU1358 mer $A$ gene to be included in the phylogenetic analysis. The robustness of the tree was confirmed by bootstrap analysis and in addition the tree topology was consistent with that generated using the method of Fitch \& Margoliash (1967) (data not shown). This $\operatorname{mer} A$ dendrogram suggests that the pMERPH mer $A$ gene is approximately equally related to that of the $T$. ferrooxidans $\mathrm{Hg}^{\mathrm{R}}$ determinant (Inoue et al., 1989) and to the subgroup of closely related Gram-negative mer determinants Tn21 (Barrineau et al., 1984), Tn501 (Brown et al., 1983), pDU1358 (Griffin et al., 1987), pKLH2 (Kholodii et al., 1993) and pMER419 (Hobman et al., 1994).

\section{Regulation of the PMERPH mer operon}

No putative regulatory genes $(m e r R$ or $m e r D$ ) were identified on analysis of the $4097 \mathrm{bp} \mathrm{Bg} / \mathrm{II}$ fragment from pMERPH, and an inducible response to sub-toxic levels of $\mathrm{HgCl}_{2}$ is not shown by the cloned determinant (data not shown). Sequence analysis of the $\mathrm{O} / \mathrm{P}$ region of pMERPH identified a number of differences from the mer regions of other Gram-negative mer determinants. -35 and -10 sequences for the mer $\mathrm{P}_{\text {TCPA }}$ promoter were found (Fig. 1), but there were no such sequences for the divergently transcribed regulatory gene (merR) which is found in all other Gram-negative plasmid-borne mer operons. Moreover the spacer region between the -35 and -10 sequences for the $\mathrm{P}_{\mathrm{TCPA}}$ promoter was $1 \mathrm{bp}$ longer than that found in other Gram-negative mer determinants such as Tn21, and only a 5 bp dyad symmetry (CCGTA-6 bp-TACGG) was found between the -35 and -10 sequences of the $P_{\text {TCPA }}$ promoter (Fig. 1) as opposed to a 6 or $7 \mathrm{bp}$ sequence in other determinants. Variation was also found in the MerR binding region (GTAG-4 bp-GTAC in pMERPH as opposed to GTAC-4 bp-G/CTAC in all other mer determinants). Promoter activity in both directions from the pMERPH mer $\mathrm{O} / \mathrm{P}$ region was investigated using the promoter probe constructs pPH112 and pPH113 (Fig. 3). Analysis of promoter activity by CAT assays showed that CAT activity increased significantly only when the pMERPH mer $\mathrm{O} / \mathrm{P}$ region was cloned such that the CAT gene was expressed from the $\mathrm{P}_{\text {TCPA }}$ promoter ( $\mathrm{pPH} 113$ ). Negligible expression was observed when this region was cloned in the opposite orientation (pPH112) (data not shown). Futhermore, addition of inducing levels of $\mathrm{HgCl}_{2}$ had no effect on CAT expression in strains containing either construct. Regulation of the pMERPH mer $\mathrm{O} / \mathrm{P}$ region was further investigated by the introduction of a transacting MerR protein, produced by the plasmid pACSE20R, into E. coli AB1157(pPH113). The presence 
1 GATCTGCTGGTGAAAGGCGGCGACTATAAACCAGAAGAGATTGCCGGGAGTAAAGAAGTCTGGGCCAACGGTGGCGAAGT 81 GTTGGTGCTCAACTTTGAAGACGGTTGCTCGACGACCAACATCATCAAGAAGATCCAACAGGATAAAAAAGGCTAACCGG 161 AAAGCGGTTCACAGATCTTGGGTTCACTTTGGAAGAAATCTCCAATTTACTCAGCCTTAATGACACTCCCTGTATAGAAG 241 TGCAAGAAATGACTTTACACAAGCTTGCAAGTGTGAAAGCCAAAATAGCAGGTCTTCGCCGCTTAGAAACCGTTCTCACA 321 GAATTATTGAATGAGTGTAATTCTAATACTAACCAATCCCACTGTCCCATTATTGATTCCCTACTTCCTGAAGATTAATA

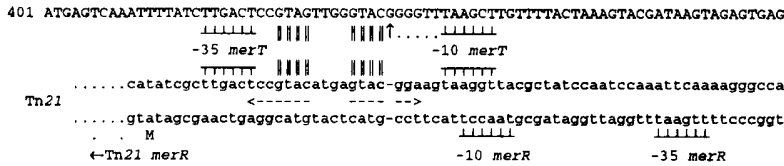
PMERPH merT $\rightarrow$

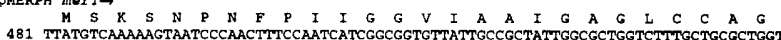
$\operatorname{Tn} 21$ mert $\rightarrow$ agtratg. $561 \underset{\text { CCTITCGTCTTGTTGCTGCTAGGCGTGAGTGGCTCCTGGATTGGTAATTTAACCTTGTTAGAACCTTATCGTCCCATTTT }}{\mathbf{P}}$

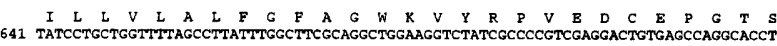
$721 \underset{\text { CCTGTGCAGTTCCTCAAGTGCGAAAACGTCGGCAGGTGATCTTTTGGTTAACGGCACTGACTGCGTTGGTITTACTCACC }}{C}$

801 AGTAATTATTGGATTGTCTGGTTCGCCTGATGACGATT2CTAACCTTTTATTTTGATTAAATCTTTATGGCTTGCTCTTE

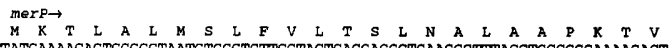
881 GAGAAAATTATGAAAACACTCCCCCTAMTCTCCCTGTCGTACTCACCACCCT $961 \underset{T A C T T T G G A A G T C C C A A C C A T G A A C T G T G T G A C C T G T C C C T T T A C C G T G G A A A A A G C C T T A C A A A A A G T C G A T G G C G T C A}{T}$ $1041 \underset{\text { GTAAAGCCGAAGTGACCTTTAAGACCAAACTGGCGGTGGTCACCTTCGACGACGAAAAATCCACGGTAAAAGCACTGACC }}{\mathbf{K}}$

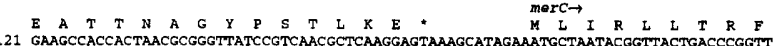
$\underset{\text { CGGCGATAAGATTAGCTCATTGGGCGCGCTGGTTTCTGCTATGGGATGCGTCATGTGTTTCCCGGCCATTGCCAGTCTGG }}{G}$ $1281 \underset{\text { GCGCTGCGGTAGGACTGGGTTTTCTCAGCCAATGGGAAGGTCTGTTTGTTAGCACGCTATTACCCCTGTTTGCCTGGATT }}{\text { A }}$ A $\underset{G}{\text { V }}$ G 1361 GCCTTGGTACTCAACGGACTTGGCTGGTTCAGCCACCGGCAATGGCACCGTAGTGCGCTGGGTGTGGCCGGCCCCATTTT $1442 \underset{\text { ATTGCTGTTATCGCTCTATCCGTTTTTCCAGTACGGCTGGAGCAGCTATGTCACCTATTCAGCATTAGGCCTGATGGTTG }}{L}$

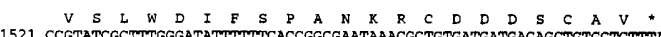

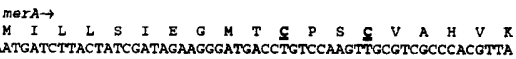
1601 cCTGACTACTATTTGMGGAAA $1681 \underset{\text { AAGAAGCACTCGATGCGATCGAAGGCGTTAATAAGGTTGAAATATCTTATGAAAACGCCAGAGCAACGATCACCACGAAC }}{\mathbf{E}}$

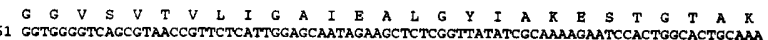
$\underset{\text { AGAAATTACTTCACCGACGACTGCTGTGACAACGAAAATGCAAGCAACACTGAAAGCAACCAAACTCAACATGTGGCGA }}{\mathbb{E}}$

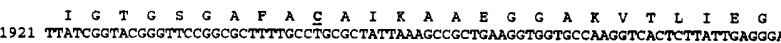
$\underset{2001}{A}$ GCCGATGTGATTGGCGGCTGTTIGCGTGAATGTCGGCTGCGTACCCTCAAAAATTCTAATCCGCGCCGCTCAATTGGCTCA $2081 \underset{\text { GCAGCAACGCAATAATCCCTTTACCGGACTGGAAATCATGCGCCCCAATTGAGTCGAGCCTTGTTGACTCAGCAGCAGA }}{Q} \underset{P}{Q}$ 2161 CCGCTCGGGTCGAAGAGCTGCGGGGGGCAAAGTACCAGATTATTCTGGAGACAAATCCTGCGCTTAGTTTACTTAAGGT

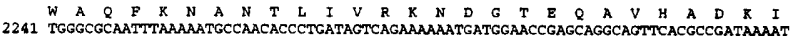

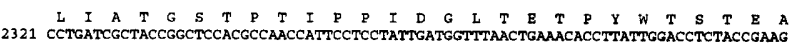
$2401 \underset{\text { CGCTGTTTGCTCAGGAATTGCCGCAGCACCTGGTCGTGATTGGTTCGTCGGTTGTAGCGCTGGAAATTGCCCAGGCTTAT }}{\text { L }}$

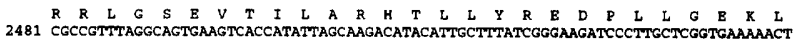

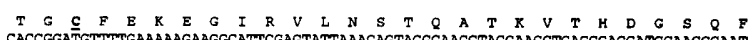
$\underset{\text { TTACATTGGAAACTAACGCGGGCGATCTACGCTGCGATCGTTTGCTGGTAAGCACCGGGCGACACGCCAATACTTGCCAA }}{T}$

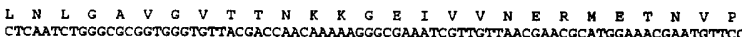
$\underset{\text { GGGTATTTACGCGGCCGGAGACTGCTTGCAACATGCGCAATTCGTCTATGTCGCCGCGCCGGCCGGTAGCCGTTCCGGCA }}{G}$

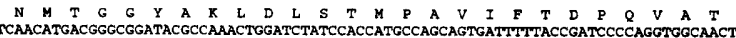

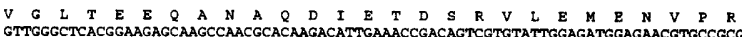
$3041 \underset{\text { CGCACTGGCGAATTTCGAGACCGATGGTTTTATCAAATTGGTGACGGAAAAAGCCACTGGCCGCCTGATCGGGGCCAGA }}{\mathbf{A}}$ $3121 \underset{\text { TRCTGGCGCATGAAGGTGGAGAACTGATCCAGAGTGCGGCGCTGGCGATCCGCAACCGTATGACGGTGACGGAATTAGCC }}{\mathrm{L}}$ $3201 \underset{\text { GACCAGCTTTTCCCTTACCTGACTATGGTGGAGGGTTTGAAGCTCTGCGCCCAAACCTTTAACAAGGATGTCAAAGAACT }}{\text { D }}$

3281 GTCCTGTTGTGCTGGGTAACGAACTTGAGTTGATCCGTATTCATTGATGGAAATGGCATTTTTCATTCGTAGTACGAAAC
3361 TGCCAATCAATTTTTTGAGTATAAGTAAAAAAGCAGTCAATTTACTATGACCTTGTTTTTTTAGGGAGGATAGATGAGCG 3441 ACCATCTGCAAATTCGTTTACCCAGTACCAATATTTTTTTTCGCTCAGGCTTAGTTCTCGACCGGTATCTTTCAGTTGTC 3521 TTTGAAATAAATGGATTAGTCCGCTTAAGCCTAAGAAGGCTAAACCGACACATAAAATTGTCCAACTCGCTTGCCAATAT 3601 GCGATTGCTAAAAACATAGTGGTGATGGTTATAAGGCCGATAGCACTAGCAATTGCTTTGAATCCCAAGTAGCTGAAAAA 3681 AACGATGGTGCAAATCAGAMATGGCAAAGCCGCTAACTTGGCAGATGCCGTTAATATTTCTGAGGGAAAAAAATGAGCCG 3761 CAGCCAAAGTCGCCAGAAAAAGCCCCAGTGATATAAACCAGCAGCGTGCTGGTAAAGATTTAAGTAATTTTATCATCTTA 3841 GTACTCTCAAAGTGCACGGGCGGTGCACAATCAAATCATGCATCAGCATGTTAGTTCTCAAAAAGTGCTCTAGTGGTTTG 3921 CTCGGCCATAATCTCACACACAGGACATTTAAGCTGAATGCGCTGTTGAGATACCGTCAAATACAGACTGCCGCATCGAC 4001 ACCGGTGTAAGGATGCAAGCTGTGATCTTAAATCACGAGCTAGAACCCAACCTTCATTGATGGTCAGT2TTTTCCAGGGG 4081 ATCTCAGCTGGAAGATC

Fig. 1. Nucleotide sequence of the PMERPH mer operon and deduced amino acid sequence of the MerT, MerP, MerC and MerA proteins. The Tn21 mer O/P region (Barrineau et al., 1984) (shown in lower case) is aligned with that of PMERPH. Putative -35 and -10 sequences are indicated by $\mu$ or $\pi$, regions of dyad symmetry by horizontal dashed arrows, and the expected site of MerR binding by vertical lines. A single vertical arrow shows the position of the extra base in the spacer region between the -35 and -10 sequences of the mer $\mathrm{P}_{\mathrm{TCPA}}$ promoter. In MerA cysteine residues which are conserved between pMERPH and Tn21 are shown in bold and are double underlined. Other cysteine residues, also in bold, are single underlined.

of a trans-acting MerR on the pMERPH mer $\mathrm{O} / \mathrm{P}$ was seen partially to repress $\mathrm{P}_{\text {TCPA }}$ promoter activity in the absence of $\mathrm{Hg}^{2+}$ ions when compared with constitutive CAT expression in the absence of MerR (Fig. 4). Addition of inducing levels of $\mathrm{Hg}^{2+}$ ions to $\mathrm{AB} 1157(\mathrm{pPH} 113$ and pACSE20R) resulted in an increase in CAT expression from the $\mathrm{P}_{\text {TCPA }}$ promoter to a level similar to that of the constitutive system (Fig. 4). Homologous control of the pMERPH mer $\mathrm{O} / \mathrm{P}$ was investigated by introducing pMERPH into E. coli AB1157(pPH113). An increase in CAT expression by AB1157(pPH113 and pMERPH) was observed above that of AB1157(pPH113) in both the presence or absence of inducing levels of $\mathrm{Hg}^{2+}$, with additional activity seen upon addition of $2 \mu \mathrm{M} \mathrm{HgCl}_{2}$ (Fig. 4).

\section{Amplification of pMERPH-like mer genes from cultivated and non-cultivated bacteria}

Using the primers $104 \mathrm{~A}$ and $103 \mathrm{~B}$, a $1.37 \mathrm{~kb} \operatorname{mer} \triangle P C \Delta A$ region was amplified by the PCR ( 30 cycles) from $E$. coli $\mathrm{AB} 1157$ strains bearing the Inc J plasmids pMERPH and R391 and from the positive control XL-1-Blue(pPH101). PCR products were also amplified from the environmental $\mathrm{Hg}^{\mathbf{R}}$ isolate SE2, which had previously been shown to bear a $\mathrm{Hg}^{\mathbf{R}}$ determinant that did not hybridize to a $\operatorname{mer} \mathrm{R} T P A$ probe from $\mathrm{Tn} 501$ at a level of $70 \%$ homology (Osborn et al., 1993). PCR products $(1.3 \mathrm{~kb}$ and $0.8 \mathrm{~kb})$ were also amplified from DNA extracted directly from bacteria from River Mersey sediment, without cultivation, following 35 cycles of PCR. No PCR products were amplified from the negative controls (sterile distilled water) in either experiment (Fig. 5a). PCR products from all the cultivated mer determinants and from the total DNA extracted from River Mersey sediment hybridized to a $4.1 \mathrm{~kb} \mathrm{BglII}$ mer probe from pMERPH at a level of homology of greater than $70 \%$ (Fig. 5b). The smaller 


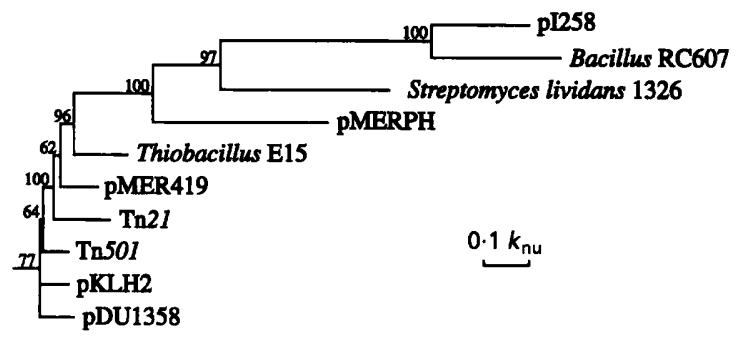

Fig. 2. Neighbour-joining distance tree of merA genes showing the evolutionary position of pMERPH. The source of other merA genes are as follows: pl258, Laddaga et al. (1987); Bacillus RC607, Wang et al. (1989); Streptomyces lividans 1326, Sedlmeier \& Altenbuchner (1992); Thiobacillus ferrooxidans E15, Inoue et al. (1989); pMER419, Hobman et al. (1994); Tn21, Barrineau et al. (1984); Tn501, Brown et al. (1983); pKLH2, Kholodii et al. (1993); and pDU1358, Griffin et al. (1987), Nucifora et al. (1989) and data from this study. The distance in $k_{\text {nu }}$ between any two sequences is the sum of the lengths of the horizontal branches between the two. Bootstrap percentages (100 replicates) are shown to the left of the node being considered.

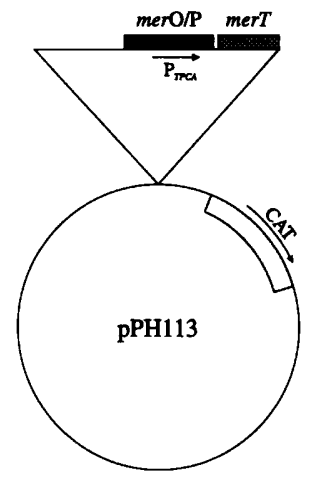

Fig. 3. Map of plasmid $\mathrm{pPH} 113$, derived from the promoter probe vector pKK232.8. The CAT gene is expressed from the $\mathrm{P}_{\mathrm{TCPA}}$ promoter in the mer O/P region. pPH112 (not shown) differs from $\mathrm{pPH} 113$ in that the mer insert is cloned in the opposite orientation.

PCR products amplified from the cultured bacteria ( $100 \mathrm{bp}$ and in addition, from SE2, one of $\sim 300 \mathrm{bp}$ ) did not hybridize to the $B g / \mathrm{II}$ mer probe.

\section{DISCUSSION}

Comparison of the PMERPH mer operon with those of previously sequenced mer determinants identified the presence of four $\operatorname{mer}$ genes $(\operatorname{mer} T, \operatorname{mer} P, \operatorname{mer} C$ and $\operatorname{mer} A)$. The predicted molecular masses of the Mer proteins calculated from the pMERPH sequence were 12.5, 9.7, 14.9 and $59 \mathrm{kDa}$ for MerT, MerP, MerC and MerA, respectively. Maxicell analysis of the polypeptides encoded by the $4.1 \mathrm{~kb} B g / \mathrm{II}$ fragment of pMERPH had identified polypeptides of 59, 22, 14 and $6.5 \mathrm{kDa}$ (Peters $e t$ al., 1991). The predicted sizes of the MerA and MerC polypeptides ( 59 and $14.9 \mathrm{kDa}$ ) are similar to the sizes of

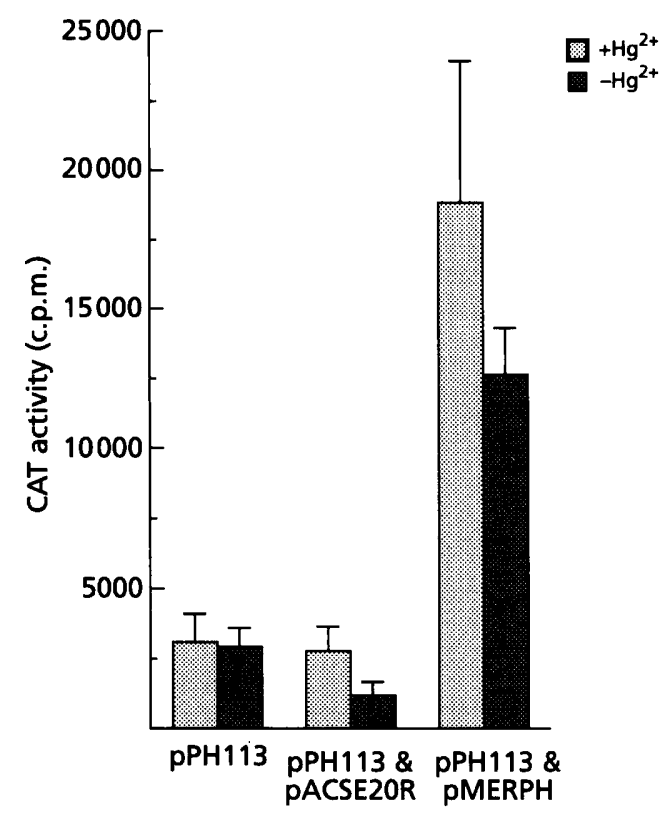

Fig. 4. The effects of repression by, and $\mathrm{Hg}^{2+}$ induction of, trans-acting MerR (transcribed on the plasmids PACSE2OR and pMERPH, representing heterologous and homologous control, respectively) on expression from the PMERPH $P_{\text {TCPA }}$ promoter as measured by CAT activity of the promoter probe construct pPH113. CAT activity values for $E$. coli AB 1157 containing the control plasmids were as follows: pKK232.8, $+\mathrm{Hg}, 119.5 \pm 30.4$,

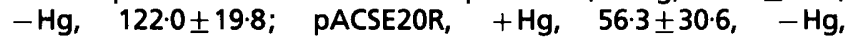
$66.0 \pm 45.4$; pMERPH, $+\mathrm{Hg}, 146.0 \pm 33.0,-\mathrm{Hg}, 126.3 \pm 40.6$.

two of the polypeptides observed in maxicell analysis. In the MerP of Tn21 a 19-amino-acid signal peptide is cleaved from the amino-terminal end to leave a 72-aminoacid processed protein (Summers, 1986). Such processing of the MerP of pMERPH would leave a protein with a predicted molecular mass of $7.7 \mathrm{kDa}$. The $6.5 \mathrm{kDa}$ polypeptide observed in maxicell analysis (Peters et al., 1991) is probably this processed form of MerP. The identity of the $22 \mathrm{kDa}$ polypeptide observed in maxicell analysis remains unknown, whilst the MerT protein may have run with the larger MerC on the SDS-PAGE gel.

Evolutionary trees derived from MerR (amino acid) and merR (nucleotide) sequences (Silver \& Walderhaug, 1992; Osborn et al., 1995) have identified a distinct subset of closely related Gram-negative mer determinants ( $\operatorname{Tn} 501$, Tn21, pDU1358, pKLH2 and pMER419) and phylogenetic analysis of the mer $A$ genes (Fig. 2) is consistent with this observation. The pMERPH mer $A$ gene is quite distinct from both this Gram-negative subgroup and from that of the $T$. ferrooxidans mer $A$ gene and suggests that the pMERPH mer determinant is the most divergent Gram-negative mer determinant characterized to date. The MerA of pMERPH is distinguished by the presence of a large number of cysteine residues, when compared against the sequences of other Gram-negative mer determinants; however the role of these additional cysteine residues is unknown. The cysteine pairs involved in $\mathrm{Hg}^{2+}$ reduction (Distefano et al., 1989; Miller et al., 1989) found 


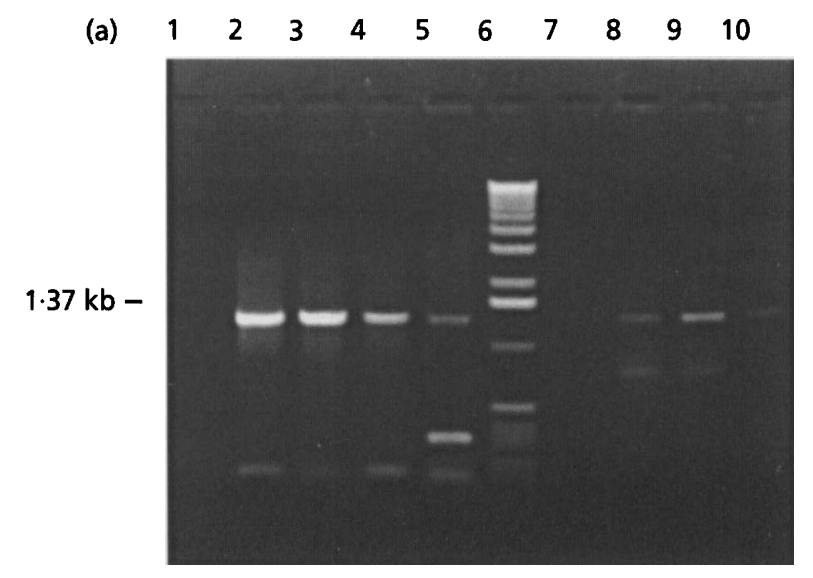

(b) $\begin{array}{llllllllll}1 & 2 & 3 & 4 & 5 & 6 & 7 & 8 & 9 & 10\end{array}$

$1.37 \mathrm{~kb}-$

Fig. 5. (a) Agarose gel electrophoresis of the PCR products amplified from cultivated and non-cultivated bacteria with the primers 104A and 103B. Lanes: 1 and 7, sterile distilled water after PCR; $2-5$, crude extracts of DNA after PCR of XL-1Blue(pPH101), AB1157(pMERPH), AB1157(R391) and SE2, respectively; 6 , kilobase ladder; $8-10,0.082,0.0082$ and $0.00082 \mu \mathrm{g}$, respectively, total DNA extracted from noncultivated bacteria from Fiddlers Ferry sediment. Lanes 1-5 are after 30 cycles and lanes 7-10 after 35 cycles of PCR. (b) Southern hybridization analysis of the agarose gel in (a) hybridized to the $B g / l l$ mer probe from pMERPH.

in the active site and at the carboxyl terminus of the Tn21 MerA are conserved in pMERPH (Fig. 1), as is the GGxCVxxGCxP motif at the MerA active site (Fig. 1, encoded by DNA from position 2013-2045). The occurrence in pMERPH of all four of the mer structural genes found previously in the mer determinants of Tn21 (Barrineau et al., 1984) and pKLH2 (Kholodii et al., 1993) suggests that the pMERPH mer determinant has diverged from a Tn21/pKLH2-like ancestor, and that the maintenance of all four structural genes is highly advantageous even in extensively diverged mer determinants. No regulatory genes have been identified adjacent to the pMERPH mer structural genes and the determinant may have evolved from a Tn21/pKLH2-like ancestor with subsequent movement of the regulatory genes to elsewhere on the pMERPH plasmid outside the region sequenced to date. Separation of the mer structural and regulatory genes has previously been seen in the chromo- somal mer determinant of T. ferrooxidans E15 (Inoue et al., 1991).

It has been shown that the mer determinants of the IncJ plasmids R391 and pMERPH fail to trans-complement Tn21 derivatives with transposon insertions in mer $\mathrm{R}$ (Foster \& Ginnity, 1985; Peters et al., 1991). In this study it has been shown that the MerR protein of the Tn21-like determinant of SE20 can both partially repress expression from the mer $\mathrm{P}_{\text {TCPA }}$ promoter and, in the presence of inducing levels of $\mathrm{Hg}^{2+}$, can induce expression (Fig. 4). This incomplete repression of the $\mathrm{P}_{\text {TCPA }}$ promoter by the MerR of SE20 may be a result of variation in the length of both the spacer region between the -35 and -10 sequences, and of the dyad symmetry in the pMERPH mer O/P region. Parkhill \& Brown (1990) have shown that increasing the spacer region from 19 to $20 \mathrm{bp}$ in the mer $\mathrm{O} / \mathrm{P}$ of $\mathrm{Tn} 501$ resulted in a reduction in induction of the promoter by MerR in the presence of inducing levels of $\mathrm{Hg}^{2+}$, and a complete loss of repression by MerR in the absence of $\mathrm{Hg}^{2+}$ ions. Twenty bp spacer regions are found in both the Bacillus RC607 and pI258 mer O/P regions (Wang et al., 1989; Skinner et al., 1991) and the additional base pair in pMERPH is at the same site as in these determinants. Helmann et al. (1989) showed that the MerR protein from $\operatorname{Tn} 501$ bound with equal affinity to both the Tn501 and Bacillus RC607 mer promoters, suggesting that the variation in length of the spacer region may not on its own be the cause of the reduced repression observed in the study of Parkhill \& Brown (1990). A reduction in both induction and repression of the $\mathrm{P}_{\text {TCPA }}$ promoter activity of $\operatorname{Tn} 501$ by MerR was observed in the mutant C565A (a substitution of A for C in the left hand GTAC box in the MerR binding region) (Parkhill \& Brown, 1990). Consequently, in pMERPH, the replacement of the $C$ in the left hand GTAC box with a $G$ (Fig. 1) may have resulted in the observed reduction in repression of $P_{\text {TCPA }}$ promoter activity in the presence of a trans-acting MerR (Fig. 4), due to a decrease in binding of the MerR to the mer $\mathrm{O} / \mathrm{P}$ region. Homologous control of the pMERPH mer O/P by pMERPH in trans resulted in a significant increase in CAT expression when compared against heterologous control by the MerR from SE20 (Fig.4), suggesting that a regulatory element must be found on the pMERPH plasmid. The homologous system appears to show an $\mathrm{Hg}^{2+}$-independent activation of transcription to levels far greater than those of the constitutive promoter, whilst addition of $\mathrm{Hg}^{2+}$ results in further activation. Such a phenomenon has previously been seen in the MerR ${ }^{\mathrm{AC}}$ double mutant of $\operatorname{Tn} 501$ where increased transcriptional activation in the absence of $\mathrm{Hg}^{2+}$ was accompanied by distortion of the mer $\mathrm{O} / \mathrm{P}$ region (Parkhill et al., 1993).

pMERPH-like sequences had previously been isolated from the River Mersey, from a clinical isolate of Proteus rettger i in South Africa (Coetzee et al., 1972), and from the River Rhine (Peters, 1988). In this study pMERPH-like sequences were amplified from both cultivated and noncultivated bacteria (Fig. 5a) from a River Mersey sediment sample collected six years after the isolation of the Pseudomonas putrefaciens strain bearing pMERPH, 
suggesting at least localized persistence of pMERPH-like sequences. It is further possible that some of the pMERPH-like sequences present may have suffered a deletion as is suggested by the amplification of $0.8 \mathrm{~kb}$ products from total DNA which hybridized to the $4.1 \mathrm{~kb}$ $B g / \mathrm{II}$ probe (Fig. 5b). In our earlier study (Bruce $e t$ al., 1992) using mer primers derived from the sequences of Tn501 and Tn21, such truncated PCR products were also amplified from soil DNA. Although these products failed to hybridize to a Tn 501 merR TP $A$ probe, partial sequence analysis suggested that these truncated PCR products were related to $\operatorname{Tn} 501$. The presence of pMERPH-like sequences around the globe, in a manner similar to that of Tn501 or pKLH2-like sequences (Osborn et al., 1995), taken together with their evolutionary distance from other Gram-negative mer determinants (Fig. 2) suggests that PMERPH-like sequences have an ancient history.

In this study the PMERPH mer determinant has been identified as the most divergent of those sequenced to date, and is probably a derivative of an ancestral Tn21/pKLH2-like determinant which has diverged considerably, especially in the mer $A$ gene and in the regulation of the operon. The determinant, although found less commonly than other Gram-negative mer determinants, has been found to persist in natural environments, and despite its apparent rarity has been found across vast geographical distances.

\section{ACKNOWLEDGEMENTS}

This work was supported by grants awarded by the Natural Environmental Research Council. This work benefited from the use of the SEQNET facility at Daresbury. The authors wish to thank Angela Bardon for data from the automated DNA sequencer. The authors would also like to thank the referees for useful comments on the manuscript.

\section{REFERENCES}

Barrineau, P., Gilbert, P., Jackson, W. J., Jones, C. S., Summers, A. O. \& Wisdom, S. (1984). The DNA sequence of the mercury resistance operon of the Inc FII plasmid NR1. J Mol Appl Genet 2, 601-619.

Birnboim, H. C. \& Doly, J. (1979). A rapid alkaline extraction procedure for screening recombinant plasmid DNA. Nucleic Acids Res 7, 1513-1523.

Brosius, J. (1984). Plasmid vectors for the selection of promoters. Gene 27, 151-160.

Brown, N. L., Ford, S. J., Pridmore, R. D. \& Fritzinger, D. C. (1983). Nucleotide sequence of a gene from the Pseudomonas transposon Tn501 encoding mercuric reductase. Biochemistry 22, 4089-4095.

Bruce, K. D., Hiorns, W. D., Hobman, J. L., Osborn, A. M., Strike, P. \& Ritchie, D. A. (1992). Amplification of DNA from native populations of soil bacteria by using the polymerase chain reaction. Appl Environ Microbiol 58, 3413-3416.

Chang, A. C. Y. \& Cohen, S. N. (1978). Construction and characterization of amplifiable multicopy DNA cloning vehicles derived from the P15A cryptic miniplasmid. J Bacteriol 134, 1141-1156.
Coetzee, J. N., Datta, N. \& Hedges, R. W. (1972). R factors from Proteus rettgeri. J Gen Microbiol 72, 543-552.

Devereux, J., Haeberli, P. \& Smithies, O. (1984). A comprehensive set of sequence analysis programs for the VAX. Nucleic Acids Res 12, 387-395.

Distefano, M. D., Au, K. G. \& Waish, C. T. (1989). Mutagenesis of the redox-active disulfide in mercuric ion reductase: catalysis by mutant enzymes restricted to flavin redox chemistry. Biochemistry 28, 1168-1183.

Fitch, W. M. \& Margoliash, E. (1967). Construction of phylogenetic trees. Science 155, 279-284.

Forster, J. W. (1984). The organisation and expression of DNA repair genes in Escherichia coli. PhD thesis, University of Liverpool.

Foster, T. J. (1987). The genetics and biochemistry of mercury resistance. Crit Rev Microbiol 15, 117-140.

Foster, T. J. \& Ginnity, F. (1985). Some mercurial resistance plasmids from different incompatibility groups specify merR regulatory functions that both repress and induce the mer operon of plasmid R100. J Bacteriol 162, 773-776.

Griffin, H. G., Foster, T. J., Silver, S. \& Misra, T. K. (1987). Cloning and DNA sequence of the mercuric- and organomercurialresistance determinants of plasmid pDU1358. Proc Natl Acad S $i$ US A 84, 3112-3116.

Helmann, J. D., Wang, Y., Mahler, I. \& Walsh, C. T. (1989). Homologous metalloregulatory proteins from both Gram-positive and Gram-negative bacteria control transcription of mercury resistance operons. J Bacteriol 171, 222-229.

Hobman, J. L., Kholodii, G., Nikiforov, V., Ritchie, D. A., Strike, P. \& Yurieva, O. (1994). The nucleotide sequence of the mer operon of pMER327/419 and transposon ends of pMER327/419330 and 05. Gene 146, 73-78.

Inoue, C., Sugarawa, K., Shiratori, T., Kusano, T. \& Kitigawa, Y. (1989). Nucleotide sequence of the Thiobacillus ferrooxidans chromosomal gene encoding mercuric reductase. Gene 84, 47-54.

Inoue, C., Sugawara, K. \& Kusano, T. (1991). The merR regulatory gene in Thiobacillus ferrooxidans is spaced apart from the mer structural genes. Mol Microbiol 5, 2707-2718.

Kholodii, G. Y., Gorlenko, Z. M., Lomovskaya, O. L., Mindlin, S. Z., Yurieva, O. V. \& Nikiforov, V. G. (1993). Molecular characterisation of an aberrant mercury resistance transposable element from an environmental Acinetobacter strain. Plasmid 30, 303-308.

Laddaga, R. A., Chu, L., Misra, T. K. \& Silver, S. (1987). Nucleotide sequence and expression of the mercurial-resistance operon from Stapbylococcus aureus plasmid pI258. Proc Natl Acad Sci USA 84, 5106-5110.

Miller, S. M., Moore, M. J., Massey, V., Williams, C. H., Distefano, M. D., Ballou, D. P. \& Walsh, C. T. (1989). Evidence for the participation of $\mathrm{Cys}_{558}$ and $\mathrm{Cys}_{559}$ at the active site of mercuric reductase. Biocbemistry 28, 1194-1205.

Misra, T. K. (1992). Bacterial resistance to inorganic mercury salts and organomercurials. Plasmid 27, 4-16.

Nucifora, G., Chu, L., Silver, S. \& Misra, T. K. (1989). Mercury operon regulation by the mer $R$ gene of the organomercurial resistance system of plasmid pDU1358. $J$ Bacteriol 171, 4241-4247.

Osborn, A. M., Bruce, K. D., Strike, P. \& Ritchie. D. A. (1993). Polymerase chain reaction-restriction fragment length polymorphism analysis shows divergence among mer determinants from Gram-negative soil bacteria indistinguishable by DNA-DNA hybridisation. Appl Environ Microbiol 59, $4024-4030$.

Osborn, A. M., Bruce, K. D., Strike, P. \& Ritchie, D. A. (1995). Sequence conservation between regulatory mercury resistance 
genes in bacteria from mercury polluted and pristine environments. Syst Appl Microbiol 18, 1-6.

Parkhill, J., Ansari, A. Z., Wright, J. G., Brown, N. L. \& O'Halloran, T. V. (1993). Construction and characterization of a mercuryindependent $\mathrm{Mer} \mathrm{R}$ activator $\left(\mathrm{MerR}^{\mathrm{AC}}\right)$ : transcriptional activation in the absence of $\mathrm{Hg}(\mathrm{II})$ is accompanied by DNA distortion. EMBO $J 12,413-421$.

Parkhill, J. \& Brown, N. L. (1990). Site-specific insertion and deletion mutants in the mer promoter-operator region of Tn501; the nineteen base-pair spacer is essential for normal induction of the promoter by MerR. Nucleic Acids Res 18, 5157-5162.

Peters, S. E. (1988). Mercury resistance plasmids in aquatic bacteria. $\mathrm{PhD}$ thesis, University of Liverpool.

Peters, S. E., Hobman, J. L., Strike, P. \& Ritchie, D. A. (1991). Novel mercury resistance determinants carried by Inc J plasmids pMERPH and R391. Mol \& Gen Genet 228, 294-299.

Saitou, N. \& Nei, M. (1987). The neighbor-joining method: a new method for reconstructing phylogenetic trees. Mol Biol Evol 4, 406-425.

Sambrook, J., Fritsch, E. F. \& Maniatis, T. (1989). Molecular Cloning: a Laboratory Manual, 2nd edn. Cold Spring Harbor, NY: Cold Spring Harbor Laboratory.
Sedlmeier, R. \& Altenbuchner, J. (1992). Cloning and DNA sequence analysis of the mercury resistance genes of Streptomyces lividans. Mol \& Gen Genet 236, 76-85.

Shaw, W. V. (1975). Chloramphenicol acetyl transferase from chloramphenicol resistant bacteria. Methods Enzymol 43, 737-755.

Silver, S. \& Walderhaug, M. (1992). Gene regulation of plasmidand chromosome-determined inorganic ion transport in bacteria. Microbiol Rev 56, 195-228.

Skinner, J. S., Ribot, E. \& Laddaga, R. A. (1991). Transcriptional analysis of the Staphylococcus aureus plasmid pI258 mercury resistance determinant. J Bacteriol 173, 5234-5238.

Summers, A. O. (1986). Organisation, expression, and evolution of genes for mercury resistance. Annu Rev Microbiol 40, 607-634.

Summers, A. O. (1992). Untwist and shout: a heavy metalresponsive transcriptional regulator. J Bacteriol 174, 3097-3101.

Wang, Y., Moore, M., Levinson, H. S., Silver, S., Walsh, C. \& Mahler, I. (1989). Nucleotide sequence of a chromosomal mercury resistance determinant from a Bacillus sp. with broad spectrum mercury resistance. J Bacteriol 171, 83-92.

Received 22 May 1995; revised 21 September 1995; accepted 17 October 1995. 